\title{
The Discourse Marker wa in Standard Arabic-A Syntactic and Semantic Analysis
}

\author{
Abdulkhaliq Alazzawie \\ English Language and Translation Program, College of Arts, ITTIHAD University, RAK, UAE
}

\begin{abstract}
Discourse markers are items (such as and, so, anyway, but, on the other hand, however) that link spans of discourse and signal various semantic and pragmatic relations. Thus, they play an important role in the cohesiveness, organization and interpretation of discourse. ${ }^{1}$ Arabic has a number of devices which play a pivotal role in the cohesion and coherence of written and spoken discourse such as wa, aw, lakin, am, fa, thuma, $b a l, l a$, etc. The present paper is limited in scope. It is an attempt to establish the constituency and identify the functions of the Arabic discourse connective device wa using resources of syntax, semantics and pragmatics. Such resources include descriptive and analytical diagnostic tools of constituency tests, structural ambiguity and semantic roles.
\end{abstract}

Index Terms - discourse, thematic roles, constituency tests, multi-functionality

\section{SIGNIFICANCE OF THE STUDY}

- As a discourse marker, $w a$ is crucial for achieving cohesion through connecting the components of discourse.

- It shows the logical and sequential relationships between utterances.

- It is an important indicator of the language user's pragmatic competence.

- It has numerous context-dependent functions.

- It has implications for Applied Linguistics in the area of language teaching, methodology and translation.

\section{FRAMEWORK OF ANALYSIS}

The present work employs standard syntactic tests of constituency and thematic roles to distinguish the constructions in which wa occurs. Discourse analysis is also employed as a framework for the analysis. The analysis is couched within the pragmatic framework of discourse analysis proposed by Fraser (1999), Feng (2010), Hatch (1992), Johnstone (2002) and Brown and Yule (1983). Fraser, for instance, proposes a binary model of discourse marker analysis in which discourse markers are classified into two groups:

A. Propositional used to relate sentence propositions. This group of markers includes:

1. Contrastive such as 'conversely', 'contrary to', 'on the other hand', 'yet', etc.

2. Collateral such as 'and', 'moreover', 'in addition to', etc.

3. Inferential such as 'thus', 'so', 'therefore', 'consequently', etc.

B. Non-propositional used to organize discourse. This group of markers includes:

1. Topic changing markers such as 'by the way', 'incidentally', 'this reminds me of'

2. Activity markers such as 'to illustrate', 'to clarify', 'to explain', etc.

3. Structure markers such as 'first', 'second', 'to begin', etc.

Feng (2010) gave a somewhat similar categorization of discourse markers:

A. Additive: 'and', 'also', 'in addition', 'furthermore', 'besides', 'similarly', 'likewise', 'for instance';

B. Adversative: 'but', 'yet', 'however', 'instead', 'on the other hand', 'nevertheless', 'at any rate', etc.

C. Causal: 'so', 'consequently', 'it follows', 'for', 'because', 'under the circumstances', etc.

D. Continuatives: 'now', 'of course', 'well', 'anyway', 'surely', 'after all', etc.

Brown and Yule (1983) defined discourse analysis as "the analysis of language in use", while Hatch (1992, p.1) defined it as the study of language communication, spoken and written. For Schiffrin (1994), it is the study of "utterances". For Johnstone (2002), discourse analysis answers many different kinds of questions about language, about participants in the conversation, and about society and culture at large.

\section{RELATED LITERATURE}

According to Schiffrin (1987, p. 65 cited in Farhan \& Fannoush, 2005, p. 2), the difficulty of investigating discourse markers lies in three factors:

A. Their multi-functionality,

\footnotetext{
${ }^{1}$ The role of discourse markers in text cohesion and coherence has been stressed in various analyses such as (Schiffrin, 1987; Blakemore, 1996; Fraser, 1999; Fareh and Hadman, 1999 and Bilimey and Monka, 2000, cited in Hamza, pp. 232-233).
} 
B. Their optionality, and

C. Their syntactic diversity.

Al Kohlani (2010) examined the function of discourse markers ${ }^{2}$ in Arabic newspaper opinion articles and classified them functionally at sentence and paragraph levels. At sentence boundaries, they are classified as: additive, contrastive, explanatory, inferential, sequential, alternative, exceptive, background, subjective and interactive. At paragraph boundaries, discourse markers express three main functions: continuity, refocus, and change of topic.

Hamza (2006) examined the use of the $w a$ in sourat Al Shams (The Sun Chapter) of the Holy Quran and correctly identified its functions in the Quranic text in this chapter. The primary function is an oath to draw attention and focus on the proposition and to add extra force to the assertion being made. The second pragmatic function is additive or collateral in Fraser's sense.

Multi-Functionality

The multi-functional nature of the conjunctive marker and in English has been pointed out and illustrated by a number of researchers (Halliday \& Hasan (1976), Baker (1992), Fareh (1998), \& Schiffrin (2003)). The conjunctive and which connects sentences, clauses and phrases can express additive, temporal, causal and adversative relations:

A. I called him and we went out. Temporal Function

B. I met John and Bill Additive Function

C. John is happy and Bill is sad. Adversative Function

In (A) and can be replaced by after that which reveals a time sequence between the two events, and in (C) it can be replaced by but or however which reveals a contrast between the two state of affairs. ${ }^{3}$

Hence, in addition to its role in the organization and cohesion of text in English, it also expresses more than one logical relation and function. These two functions - as a cohesive device and as a functional discourse operator - should be clearly distinguished.

\section{DESCRIPTION ARABIC WA,}

Like English, Arabic has an expression wa which, in addition to its role in text cohesion, expresses different functions described below:

\section{A. Introductory $\mathrm{Wa}$}

This form frequently appears at sentence- and paragraph- initial position. It serves a general introductory function for beginning a topic. In studies of Arabic grammar and rhetoric, this version of wa gis termed waw واو الإستئناف, an initiator or a mere filler as it has no propositional content.

وِ وُلد نجيب محفوظ في حي الجمالية وِهو أحد الأحياء الثتعبية في القاهرة ويقع بجانب مسجد الحسين بالأزهر . و

1. Wa wilida Najeeb Mahfouth fi hai aljamaliyya wa hwa ahad igahiya'a alshabiyya fil qahira wa yaqau bijanib masjid Alhusain bilazzhar wa

كان و الده موظفاً حكوميأ ثم عمل في التجارة بعد ذللك

2. Kana waliduhu muwwathafan hukumiyyan thumma amila filtijara bada thalika

"Najeeb Mahfouth was born in Aljamaliyya neighborhood; it is one of the poorer neighborhoods in Cairo located near Al Husain mosque in Al Azhar. His father worked for the government; then in trade."

\section{B. It Can Be a Conjunction of Two or More Entities, Events or Propositions}

اثترى علي بيتا ومتجرا

3. Ishtara Aly baytan wa matjaran

"He bought a house and a store."

زارنا محمد وعلي

4. Zarana Muhamadun wa Alyun

"Muhammad and Aly visited us."

استمع لمعلكك، وِحاول الفهم ، وِناقتشه في الأمر الصعب

5. istami' limualimmika wa hawil alfahm wa naqishhu filamr als'ab

"Listen to your teacher, try to understand (what he says) and discuss the difficult points with him."

This conjunction is a recursive process, that is to say iterative in the sense that there is no upper limit to the number of times it can apply. More than two entities, modifiers or events can be conjoined by wa:

عمر وخالد وفاطمه وسعيد

6. Omar wa Khalid wa Fatima wa Saeed

"Omar, Khalid, Fatima and Saeed"

$$
\text { ازرق واحمر واسود واصفر }
$$

\footnotetext{
${ }^{2}$ Different terms have been used for discourse markers: linking adverbials Biber et al. (2002, p. 237), conjunctive adjuncts or conjunctive expressions (Halliday \& Hasan, 1976), discourse particles or discourse markers (DM) (Schiffrin, 1986, cited in Müller, 2005, p.5). Cue phrases and clue words are also used.

${ }_{4}^{3}$ It might be good to keep in mind that the same function can also be expressed by more than one marker.

21 - 27 مذكرات في أدوات الربط والوصل في اللغة العربية محمود عبد الله جفال الحديد (2004). 4
} 
7. Azraq wa ahmar, wa aswad, wa asfar

"blue, red, black and yellow"

لعب و اكل وشرب وقفز ووقع

8. Laiba wa akala wa shariba wa qafaza a waqaa

"He played, ate, drank, jumped and fell down."

هذا و هذه وذالك وتلك وهو لاء

9. Hatha wa hathihi a thalika wa tilka a haula

"this (masculine), this (feminine), that (close to speaker, that (farther from speaker) and those."

Note that, unlike English, the conjoiner must be repeated with each new expansion of the structure.

\section{Adjunct Marker}

It can introduce a unit of discourse functioning as an adjunct to modify an event.

جاء رامي و هو راكبا فرسه

10. Ja’a Rami wa huwa rakiban farasahu

"Rami arrived riding his horse."

\section{Oath Marker}

It can mark an oath signaling the speaker's attitude towards the truth condition of the proposition.

والهّ

11. Wallahi

"(I swear) by God."

\section{E. Path}

It can mark a path ${ }^{5}$ semantic or thematic role as in the following sentence:

مشيت و النهر من الجامعة الى الكهف

12. mashytu wa lnahra min aljamiati ila alkahfi

"I walked along the river from the university to the cave".

The phrase wa lnahra is the path; it denotes the interim points between the source - the starting point of the motion aljamiati and the goal alkahfi - the resting point of the motion. The path role is associated with verbs of motion and indicated by $w a$ in the example above. ${ }^{6}$

\section{F. Companionship and Association}

It can mark Companionship and an Association semantic role as in:

مشيت ومحمدا

13. a. mashaytu wa Muhamadan

"I took a walk with Muhammad."

سرت و الو ادي

14. Sirtu wa lwadiya ${ }^{7}$

"I walked along the valley."

خرجنا وغياب الثمس

15. kharjna wa giyaba alshamsi

"We went out at sunset."

Kreidler (1998, p. 76) adopted the term Associate instead of Companionship and gives the following example where Ann is the Associate:

Tom is with Ann.

In summary, wa has several different functions in Arabic discourse: as a coordinating conjunction, as a text organizer marking sentence boundaries, as a preface to sentential or lexical adjuncts, as an expression of an affirmative oath and as an expression of Path and Associate thematic role. Some of these points will be justified using syntactic constituency tests in the following section.

\section{ANALYSIS AND ARgumENTATION}

\section{A. Initiation}

Here $w a$ is frequently used, always sentence-initially, and its function is to textually relate sentences to each other. It is a cohesive device or a text-building device (Halliday \& Hasan, 1976) widely used by writers and speakers and expected by hearers to establish ties between sentences and to indicate continuity of discourse. However, this functional item makes no semantic or syntactic predictions about the internal structure of the following sentence it is prefaced to. ${ }^{8}$

\footnotetext{
${ }^{5}$ On path thematic role, see (Kreidler 1998, p. 118).

${ }^{6}$ Other indicators of the path thematic role include ibra 'via', min khilal 'through', an tariq 'by way of' and bimuhathat 'along'.

${ }^{7}$ This example is taken from عبد الرؤوف زهدي و سامي أبو زيد (2011, p. 227)

${ }^{8}$ For a similar statement in connection with the English pragmatic marker "please", see Stubbs (1983).
} 
In fact, the sentence would be propositionally complete without wa. This does not, however, mean that it is superfluous or redundant and therefore dispersible because it does signal some aspect of meaning, such as slight topic shifting or slight refocusing of discourse.

\section{B. Conjunction}

The standard syntactic tests of questions, substitution, and dependency show that wa functions as a conjunction. ${ }^{9}$

1. Questions

Evidence that wa conjoins two noun phrase constituents comes from questioning. Consider the noun phrases in:

اشترى علي بيتا كبير ا ومتجر ا صغير ا

16. ishtara Alyun baytan kabiran wa matjaran sagiran.

"Aly bought a big house and a small store."

ماذا اشترى علي

17. maatha ishtra Alyun?

"What did Aly buy?"

مات الطالب و المدرس

18. maata altalibu wa lmuddarrisu

"The student and the teacher both died."

من مات

19. man maata?

"Who died?"

In each case, wa links two noun phrases which have the same function and behave together as a unit.

2. Substitution by a phonologically null pronoun

Each member noun phrase in the conjunction can be substituted for by a null pronoun licensed by a proximal demonstrative:

اشترى هذا وهذا

20. ishtra hatha wa hatha

"He bought this (one) and this (one)."

اشتر اهم

21. ishtarahuma

"He bought them."

Or, alternately, one accusative pronoun suffixed to the predicate may replace the entire set resulting in a morphologically complex segment as in (21).

\section{Dependency}

A dependency relation exists between the categories in the conjoined set and wa. The asterisk indicates an ungrammatical sentence. Sentence (22) fails because the second noun phrase of the conjunction is omitted. Sentence (23) also fails because the first noun phrase of the conjunction is omitted.

اشترى علي بيتا كبيراو

22. *Ishtara Aly baytan kabiran wa

اشترى علي و متجر ا صغير ا

23. *Ishtara Aly wa matjaran sagiran.

4. Government and Case assignment ${ }^{10}$

The verb governs the whole set in the conjunction and assigns accusative Case to it. Both noun phrases, the one preceding $w a$ and the one following it, carry accusative Case and both fulfill the same grammatical and semantic functions. This indicates that wa marks conjunction as in:

كتب علي مقالة ورسالة

24. kataba Alyun maqalatan wa risalatan

"Aly wrote an article and a letter."

\section{Passivization}

The whole set in (24) above can undergo passivization behaving as a unit in a topic position of focus (25), but its members cannot be disjointed to achieve similar focus (26 and 27):

$$
\text { كتبت مقالة ورسالة من قبل علي }
$$

25. kutibat maqalatu wa risalatu min qibal Aly

"An article and a letter were written by Aly."

كتبت مقالة من قبل علي ورسالة

26. *Kutibat maqalatu min qibal Aly wa risalatu.

“*An article was written by Aly and a letter."

كتبت رسالة من قبل علي و مقالة

27. *Kutibat risalatun min qibal Aly wa maqalatun.

\footnotetext{
${ }^{9}$ For some of these tests, see Radford (1988, p. 90).

${ }^{10}$ On government and Case assignment, see Chomsky $(1981,1986 b)$ and subsequent work.
} 
“*A letter was written by Aly and an article."

Their separation through repositioning will alter the meaning drastically and produces a different construction:

كتبت مقالة من قبل علي، ورسالة، أيظا

28. Kutibat maqalatu min qibal Aly, wa risalatu, [VP], aythan

"An article was written by Aly, and a letter, [VP], also."

In these forms, verb phrase deletion has applied, the collateral or additive discourse operator is normally added and a comma before $w a$ 'and' is inserted.

The conclusion from these tests is that this instance of $w a$ is a discourse marker of conjunction. The noun phrase arguments thus conjoined have the same syntactic and semantic functions. They form constituents and therefore cannot be separated without changing the meaning and the construction.

\section{Wa Signaling Path Semantic Role}

This form of $w a$ is typically associated with predicates of motion and transition. Such predicates express the movement of some entity from one place to another. wa merely acts as a link between the predicate and its path semantic role:

مشى المسافر و الصحر اء الى القرية

29. masha lmusafiru wa lsahara ila qaratihi

"The traveler walked along the desert to his village."

سرناوشاطئ البحر الى الكوخ

30. Sirna wa shati'a albahri ila alkoukhi

"We walked alongside the sea coast to the cottage."

Verbs such as masha "walked", sara "went", thahaba "left", ja'a "came" express motion, going and coming from one place to another. The distance between the starting point of the motion and the final destination is known as the Path. Wa is a linking or relational marker meaning along side.

\section{Association}

It should be noted that the standard term adopted in Arabic grammar for Path is Association which simply means that there is an association in space between the theme semantic role (the goer or traveler) and the desert or the sea coast. The association is only spacial, alongsidedness, and is limited to adjacency only. It is not a mutual semantic association in terms of motion; the verbal predicate of transition is not a shared constituent as the desert does not travel nor does the sea coast possess voluntary will and motion. Thus, the conjunction interpretation of equally sharing the activity is excluded. The motion of leaving, coming, crossing, entering and climbing entails some geographical landmark along which the movement is carried out at a specified time (though the time frame does not have to be mentioned but it is always understood as a component of the proposition).

The term 'Association' is intended in a very general sense to include, as will be discussed below, special/location (31), temporal (32), thematic relations (33-34) and associate (35):

$$
\text { سيرك و الثاطئ مفيد }
$$

31. sayruka wa lshatia mufidun

(Spacial/location)

"Your taking a walk along the coast is useful."

رجع و الدي من السفر وطلوع الفجر

32. raja walidi min alsafari wa tulua alfajri

"May father came back from the trip at daybreak."

جلس الطالب و الكتاب

33. Jalasa altalibu wa lkitaba

"The student sat in the company of the book."

كل طالب وطريقته في الدر اسة

34. kulu talibin wa tariqatahu fil dirasati

"Each student has his own way of studying."

ذهب حسن و عليا

35. thahaba Hasanun wa Alyan

"Hasan left in Aly's company."

(Temporal: Locating an event in time)

It should also be noted that the noun phrase following wa is invariably marked with the morpheme suffix -a or with its variant -an. The grammarians of Arabic have taken this morphological marker to be an accusative Case. However, this form seems to be a fossilized default marker characteristic of a set of categories for which there is no obvious Case assigner such as the absolutive and some other adjuncts. In the above examples masha and sara are intransitive which cannot assign accusative Case.

The theme reading can be obtained by adding a resultative clause as in:

جلس الطالب والكتاب فوجده خير جليس

36. Jalasa altalibu wa lkitaba fawajadahu khayara jaleesin 
"The student sat with his book (as if it were his company) and he found it to be the best companion." 11

\section{Associate and Actor: Minimal Pair}

ذهب حسن و علي الى السوق

37. thahab Hasanun wa Ala'un ila alsouqi Conjunction of two Actors

"Both Hasan and Ala went to the market."

ذهب حسن و عليا الى السوق

38. thahab Hasanun wa Alyan ila alsouqi Actor and Associate

"Hasan accompanied by Aly went to the market."

The two examples can be differentiated on the basis of their Case and semantic relations. In (37) wa signals a conjunction of two Actors Hasan and Aly; both function grammatically as the subject and bear the nominative Case. The two Actors are active participants in the event and its course and planning.

In (38), however, $w a$ fulfills an entirely different role. Note that the Case on the NP Hasan, the NP preceding wa is nominative while the Case of Aly, the NP following $w a$, is a default fossil coterminous with the accusative form. The principal participant in the communicative act in terms of initiation, direction, purpose and execution is Hasan, the Actor. The Actor instigates and determines the course of the process from the beginning and actively controls what is happening - the event. On the other hand, the NP Aly has a different semantic property. It is the Associate signalled by $w a$ 'with', not the instigator. It is present throughout the communicative act but does not control it, nor is it involved in its intentionality.

\section{Testing the Two Structures}

The following example shows that the Actor and Instigator imply intent; it is modifiable by adverbs such as purposely, intentionally, deliberately and other adverbials:

ذهب حسن و عليا الى السوق مسرعا

39. thahab Hasanun wa Alyan ila alsouqi musri'an

"Hasan accompanied by Aly went to the market in a hurry."

قتنل حسن و عليا الرجل عمدا

40. qatal Hasanun wa Alyan alrajula 9amdan

"Hasan accompanied by Aly killed the man deliberately."

The adverb refers to the activity performed by the Actor, the controller of the event, not to the Associate. This shows Hasan, as an Actor, has intentional control over the situation and that he is primarily and exclusively involved in instigating and committing the murder. It is not entirely clear from sentence interpretation if the Associate is an accomplice in the crime in some way. We know he has no willful control and happened to be in motion at the same time in the wrong company. The adverb test indicates that he has no input or contribution to the act. Being a companion at the time of the criminal event, however, might implicate him though.

\section{Inclusion of a Timeframe}

The distinction between the two markers can also be made on the basis of including a timeframe: ${ }^{12}$

$$
\text { جاء حسن وعلي قبله }
$$

41. Ja'a Hasanun wa Alyun qablahu

رأيت حسنا وعليا قبله (unacceptable)

42. *Ra'aytu Hasana wa Alyan qablahu

(41) is a conjunction where consecutive ordering is acceptable. In other words, it is understood as communicating that the state of affairs, expressed by the predicate $j a^{\prime} a$ and described in the conjuncts, occurred in a temporal sequence. (42) is an Associate structure where consecutive ordering is unacceptable as it is in conflict with the notion of togetherness in time. Therefore, the sentence accepts a conjunction interpretation only which does not necessarily imply concomitance and temporal ordering of the state of affairs.

Similarly, the following wa can only express a conjunction since the timeframe is open, as indicated by qabl or ba9da, whereas the Associative wa expresses a single event at the same point in time.

جاء حسن و علي قبله او بعده

43. ja'a Hasanun wa Alyun qablahu aw ba9dahu

"Hasan and Aly both but Aly came either before or after Hasan."

\section{Symmetrical and Reciprocal Predicates}

In some cases, the predicate gives information about the type of structure. ${ }^{13}$ For example, tashajara "quarrel", takhasama "argued", takataba "corresponded", tasabaqa "competed", and "taqatal" "fought" are reciprocal predicates which signal mutual sharing, reciprocity and symmetry, as in the following conjunction in which two Agents are conjoined and assigned nominative Case:

\footnotetext{
${ }^{11}$ An alternate translation can be "The student, in the company of his book, found it to be the best companion." Or "The student, accompanied by his book, found it to be the best companion."

${ }^{12}$ These sentences are taken from عبد الرؤوف زهدي و سامي ابو زيد (2011,p. 228)

${ }^{13}$ Baker (1992) points out that not only conjunctions but verbs can also express semantic relations. For example, follow and precede express temporal relations, as in: A snowstorm followed the battle. The sentence can be expressed as: They fought the battle. After that, it snowed.

Also verbs like cause and lead to express causal relations.
} 
تقاتل حسن و علي

44. taqatal Hasanun wa Alyun.

"Hasan and Aly fought with each other."

In the above example, we are informed by the predicate that the conjuncts, the two referring expressions, are in a converse relationship. Hasan fought with Aly, and Aly with Hasan. The relationship can also be expressed by two separate sentences:

قاتل حسن عليا

45. Qaatal Hasanun Alyan

"Hasan fought with Aly."

قاتل علي حسنا

46. Qaatal Alyun Hasanan

"Aly fought with Hasan"

The action is reciprocal and symmetrical.

Such predicates can also express an Associative meaning as in (47). Note this time the two NPs are assigned different

Cases, the one preceding $w a$ is nominative but the one following it is accusative:

تقاتل حسن و عليا

47. taqatal Hasanun wa Alyan.

"Hasan had a fight with Aly."

Here, the primary active Agent is Hasan as it holds the predicational relation with the verb. Hasan is the Associate, not the participant, because it is not predicated of the verb in spite of the reciprocal meaning of the predicate. If Hasan fought with Aly, it is not necessarily true that Aly fought with Hasan; the two referring expressions are in a reciprocal relationship, not symmetrical.

\section{Ambiguity}

Further evidence for the distinction comes from structural ambiguity:

قابلت حسنا و عليا

48. Qabaltu Hasana wa Alyan.

"I met Hasan and Aly."

Under the conjunction interpretation, the two individuals were met either separately or concurrently, and the focus of the meeting is on both since they equally function as Theme. Under the Associative interpretation, both of them were there together at the same meeting at the same time; the focus of the meeting is Hasan while Aly is a peripheral companion.

The conjunction structure is also open to another interpretation where Hasan and Aly had a fight with some else, perhaps with the manager, for example, as the structure can be the result of prepositional phrase ellipsis:

تقاتل حسن و علي مع المدير

49. taqatal Hasanun wa Alyun ma'a almodeer.

"Hasan and Aly had a fight with the manager."

\section{CONCLUSION}

This paper offered a detailed description of the discourse marker $w a$ in Arabic, its multi-functionality and classification into: Initiator of discourse, conjunction, marker of temporal and manner adjuncts and marker of Associative and Path semantic roles. Diagnostics for constituency structure were used to distinguish the structures with which each marker is in construction, and to establish the semantic functions. A valid distinction is made between Associative, Path and temporal categories on the basis of their syntactic behavior and semantic import. These categories are lumped together in Arabic grammatical treaties under the heading Associative object. This is an important area for further investigation to advance our understanding of the issues.

While some of these markers have been the subject of extensive research in English, the Arabic ones have received less attention from a semantic - pragmatic perspective. This paper is intended to be a basis for further investigation into the nature of discourse and pragmatic markers of Arabic. It is important to highlight the systematic investigation of discourse markers in both languages, Arabic and English, in a contrastive manner and reveal its implication for foreign language teaching and translation. Future research is needed to address the issue and shed some light on its consequences for language education.

\section{ACKNOWLEDGEMENT}

I am grateful to Dr. Safaa Eissa, Dean of Arts, ITTIHAD University for her comments and encouragement.

\section{REFERENCES}

[1] Al Hadeed, M. (2004). Muthakarat fi adawat alrabt walwasl fi allugha alarabiya. Aljamia alarabiya almaftouha.

[2] Al Kohlani, F. A. (2010). The Function of Discourse Markers in Arabic Newspaper Articles. Ph.D. Dissertation, Georgetown University. 
[3] Baker, M. (1992). In Other Words: A Course Book on Translation. London, England: Routledge.

[4] Biber, D., Conard, S. \& Leech, G. (2002). Student Grammar of Spoken and Written English. Edinburgh: Longman.

[5] Brown, G. \& Yule, G. (1986). Discourse Analysis. Cambridge: Cambridge U. Press.

[6] Chomsk, N. (1981). Lectures on Government and Binding. Dordrecht: Foris publications.

[7] Fareh, S. (1998). The function of and and wa in English and Arabic written discourse. Papers and Studies in Contrastive Linguistics, 34, 303-312. Retrieved April 10, 2014 from http://www.ifa.amu.edu.pl/psicl/files/34/18Fareh.pdf.

[8] Farhan, Z. \& Fannoush, T. (2005). Difficulties of Translating Discourse Markers From English Into Arabic. $A D A B A L-$ RAFIDAYN 42, 1-27. Retrieved March 12, 2014 from http://www.iasj.net/iasj?func=issueTOC\&isId=2246\&uiLanguage=ar.

[9] Feng, L. (2010). Discourse Markers in English Writing. Journal of International Social Research, 3/11, Spring 2010. Retrieved January 15, 2014 from http://www.sosyalarastimalar.com.

[10] Fraser, B. (1999). What are DMs?. Journal of Pragmatics, 31, 931-925.

[11] Hamza, M. (2006). Discourse Markers in Written Arabic. Teachers' College Researchers Journal, 1, No. 1, 1-252 Retrieved February 26, 2014 from http://www.basiceducation.uomosul.edu.iq.

[12] Halliday, M. \& Hasan, R. (1976). Cohesion in English. London: Longman.

[13] Hatch, E. (1992). Discourse \& Language Education. Cambridge: Cambridge University Press.

[14] Johnstone, B. (2002). Discourse Analysis. Malden: Blackwell.

[15] Kreidler, C. (1998). Introducing English Semantics. London: Routledge.

[16] Müller, S. (2005). Discourse Markers in Native and Non-native English Discourse. Amsterdam, Netherlands: John Benjamins.

[17] Radford, A. (1988). Transformational Grammar: A First Course. Cambridge: Cambridge University Press.

[18] Schiffrin, D. (2003). Discourse Markers: Language, Meaning and Context. In Schiffrin, D, D. Tannen and Heidi, E. Hamilton (eds). The Handbook of Discourse Analysis. Blackwell Publishing, Blackwell Reference. http://www.blackwellreference.com/subscriber/book? Retrieved April 4, 2014.

[19] Stubbs, M. (1983). Discourse Analysis: The sociolinguistic analysis of Natural Language. Chicago: University of Chicago Press.

[20] Zuhdi, A \& Abu Zayd, S. (2011). Aljami fil Nahw. Silsilat almaharat fil luga alarabiyya (3). Maktabat Alfalah.

Abdulkhaliq Alazzawie, holds a Ph.D. degree in Linguistics from Simon Fraser University, Canada, in 1991, an M.A. in Linguistics from University of Ottawa in 1985.

He is currently an assistant professor at ITTIHAD University, RAK, UAE. He has already published one research paper entitled: "Yamawwad: A Discourse and Pragmatic Marker in Iraqi Arabic". His research interests include English/Arabic Syntax within the Government and Binding Theory of Noam Chomsky, Case assignment, adjunction, anaphor binding, Syntax-Morphology interface, and Morpho-phonemic interaction.

Dr. Al-Alazzawie has worked in the Department of Linguistics, Simon Fraser University and University of Victoria where he taught English Syntax, English and Arabic Morpho-syntactic Structures (post graduate level). He has taught English conversation, grammar, vocabulary building and composition in the English Language Society and English Language Academy, Oska, Japan. 